\title{
STUDI KEPUASAN PELANGGAN TERHADAP KINERJA JASA LAYANAN PDAM DENGAN METODE IMPORTANCE PERFORMANCE ANALYSIS
}

\author{
Dion Achmad Armadi, Hendro Sasongko, dan Doni Wihartika \\ Universitas Pakuan, Bogor \\ Email: dionachmad@unpak.ac.id
}

\section{KETERANGAN ARTIKEL}

Diterima: 1 Mei 2019

Direvisi: 1 Juni 2019

Disetujui: 31 Juni 2019

Klasifikasi JIEL

L15

\section{Keywords: Customer Satisfaction, Importance} Performance Analysis, PDAM

\begin{abstract}
Customer satisfaction, emotional bonding, trust, choice reduction and habit, too history with company is a key factor for convince the customer to use product and services continue, the other factors can make customers become loyal to the quality of products and promotions. This study aims to measure the performance of services provided by regional companies such as PDAM to the community, the level of customer satisfaction is a reflection of the company's performance, a measurable data is needed that is taken directly to customers. With the help of the Importance Performance Analysis method, performance can be measured and easily understood by decision makers. So that poor performance can be seen and anticipated for future needs. Customer satisfaction of PDAM reaches $74.49 \%$ with the main priority that needs to be improved from the services provided are the ability of Social Media Admin \& Website Officers with performance indicator values of 2.93 and importance indicator values of 3.10. (D.Quadrant Concentrate Here).

ABSTRAK

Kepuasan pelanggan, ikatan emosi, kepercayaan, kemudahan, serta pengalaman dengan perusahaan merupakan faktor kunci loyalitas pelanggan untuk menggunakan sebuah produk dan jasa secara terus menerus, faktor lain yang dapat membuat pelanggan menjadi loyal kualitas produk dan promosi . Penelitian ini bertujuan untuk mengukur kinerja pelayanan yang diberikan perusahaan daerah seperti PDAM kepada masyarakat, Pengukuran tingkat kepuasan pelanggan merupakan cerminan dari kinerja perusahaan, maka untuk mengukur kinerja diperlukan suatu data terukur yang diambil langsung kepada para pelanggan. Metode yang digunakan dalam penelitian ini adalah Importance Performance Analysis (IPA), kinerja dapat diukur dan mudah untuk dipahami oleh para pengambil keputusan. Berdasarkan hasil analisis yang dilakukan diperoleh tingkat kepuasan pelanggan PDAM mencapai $74,49 \%$ dengan prioritas utama yang perlu diperbaiki dari layanan yang diberikan adalah kemampuan petugas admin media sosial \& website dengan nilai indikator kinerja sebesar 2,93 dan nilai indikator kepentingan 3,10, (kuadaran D. Prioritas Utama).
\end{abstract}

\section{PENDAHULUAN}

Kota Bekasi mengalami permasalahan dalam penyediaan air khususnya air permukaan yang saat ini telah tercemar, (SuaraJabar, 2019). Adanya UU otonomi daerah mengakibatkan adanya dua sistem 
pengelolaan air di Kota Bekasi yaitu PDAM Tirta Bhagasasi Bekasi dan PDAM Tirta Patriot.

Menurut Esanawati (2009) pemenuhan kebutuhan Air di Kota Bekasi yaitu kebutuhan total daerah dan cakupan pelayanan baru sekitar $25 \%$ dari total cakupan pelayanan, dengan asumsi kebutuhan air perkotaan digunakan 185 liter/detik.

Kepuasan pelanggan merupakan faktor yang sangat penting dan menentukan bagi pencapaian tujuan perusahaan, oleh karenanya faktor kepuasan pelanggan harus menjadi prioritas utama perusahaan daerah seperti PDAM.

Kualitas jasa PDAM harus dimulai dari kebutuhan pelanggan dan berakhir pada persepsi pelanggan. Hal ini berarti bahwa citra kualitas jasa PDAM yang baik bukanlah berdasarkan sudut pandang atau persepsi pihak penyedia jasa, melainkan berdasarkan sudut pandang atau persepsi pelanggan. Pelangganlah yang mengkonsumsi dan menikmati jasa perusahaan, sehingga merekalah yang seharusnya menentukan kualitas jasa.

Berdasarkan hal tersebut maka perlu diketahui, bagaimana penilaian pelanggan atas kinerja jasa layanan yang diberikan PDAM Bekasi kepada para pelanggan.

\section{KAJIAN LITERATUR}

\section{Kepuasan Pelanggan}

Kepuasan pelanggan menurut J. Supranto (2011:233) didefinisikan sebagai wujud perasaan konsumen setelah membandingkan kinerja atau hasil yang dirasakan dengan yang diharapkannya. Menurut Tjiptono (2008) Kualitas pelayanan mencerminkan perbandingan antara tingkat pelayanan yang diberikan oleh perusahaan dibandingkan dengan ekspetasi atau harapan konsumen. Kualitas pelayanan diwujudkan melalui pemenuhan kebutuhan dan keinginan pelanggan serta ketepatan penyampaian dalam mengimbangi atau melampaui harapan pelanggan. Menurut Zeithaml (2000) kepuasan pelanggan dipengaruhi oleh empat faktor, yaitu fitur produk dan layanan, emosi konsumen, pendukung sukses maupun gagalnya pelayanan serta persepsi keadilan konsumen. Adapun model kepuasan pelanggan menurut Zeithaml (2000) adalah sebagai berikut:

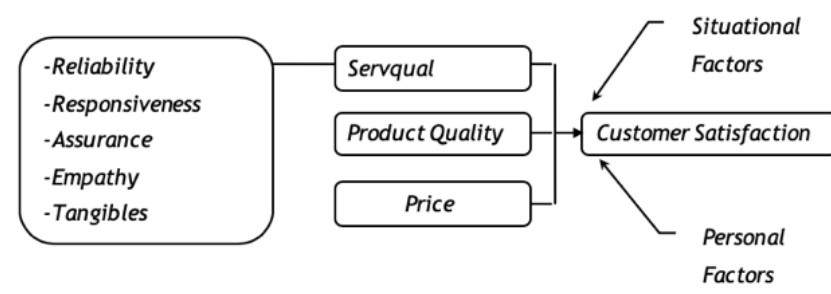

Sumber: Zeithaml (2000)

\section{Gambar 1. Model Kepuasan Pelanggan}

Pada Gambar 1 di atas, Zeithaml (2000) mengemukakan bahwa kepuasan adalah konsep yang jauh lebih luas dari hanya sekedar penilaian kualitas pelayanan, tetapi dipengaruhi juga oleh faktor-faktor lain. Sebagaimana terlihat pada gambar diatas kepuasan pelanggan dipengaruhi oleh persepsi pelanggan terhadap kualitas pelayanan (jasa), kualitas produk dan harga. Kualitas pelayanan (jasa) merupakan fokus penilaian yang merefleksikan persepsi pelanggan terhadap lima dimensi spesifik dari pelayanan (jasa), yaitu rreliability, responsiveness, assurance, emphaty, dan tangibles. Model kepuasan pelanggan dari Zeithaml ini digunakan dalam penelitian karena dimensi-dimensi yang mempengaruhi kepuasan pelanggan mempengaruhi objek penelitian.

\section{Pengertian Pelanggan}

Menurut Zulian Yamit (2005) secara tradisional pelanggan diartikan orang yang membeli dan menggunakan produk. Dalam perusahaan yang bergerak di bidang jasa, pelanggan adalah orang yang menggunakan jasa pelayanan. Menurut Greenberg (2010:08) pelanggan didefinisikan sebagai sebuah individu atau kelompok yang melakukan pembelian atas sebuah produk atau jasa berdasarkan pada keputusan akan pertimbangan harga dan penawaran yang 
berkomunikasi dengan perusahaan melalui surat, panggilan telepon, dan email yang dikirimkan secara berkala.

\section{Kualitas Jasa}

Melalui serangkaian penelitian, Parasuraman dalam Parasuraman et al. (1985) menyusun lima dimensi utama kualitas jasa yang disusun sesuai urutan tingkat kepentingan relatifnya sebagai berikut: Pertama, bukti fisik (tangibles), berkenaan dengan daya tarik fasilitas fisik, perlengkapan dan material yang digunakan instansi, serta penampilan karyawan. Kedua, reliabilitas (reliability), berkaitan dengan kemampuan instansi untuk memberikan layanan yang akurat sejak pertama kali tanpa membuat kesalahan apapun dan menyampaikan jasanya sesuai dengan waktu yang disepakati. Ketiga, daya tanggap (responssiveness), berkenaan dengan kesediaan dan kemampuan para karyawan untuk membantu konsumen dan merespon permintaan mereka, serta menginformasikan kapan jasa akan diberikan dan kemudian memberikan jasa secara cepat.

Keempat, Jaminan (assurance), yakni perilaku para karyawan mampu menumbuhkan kepercayaan konsumen terhadap instansi dan instansi bisa menciptakan rasa aman bagi para konsumennya. Jaminan juga berarti bahwa para karyawan selalu bersikap sopan dan menguasai pengetahuan dan keterampitan yang dibutuhkan untuk menangani setiap pertanyaan atau masalah konsumen. Hal ini terdiri dari: a) competence: menunjukan ketrampilan dan pengetahuan pegawai untuk melakukan pelayanan, b) courtessy: menunjukan sopan-santun, rasa hormat, tanggung jawab, dan keramahan pegawai, c) credibility: menunjukan keparcayaan dan kejujuran dari penyedia jasa, dan d) security: menunjukan kemampuan penyedia jasa agar pelanggan bebas dari bahaya dan resiko yang mungkin terjadi.
Kelima, empati (empathy), instansi memahami masalah konsumennya dan bertindak demi kepentingan konsumen, serta memberikan perhatian personal kepada konsumen dan memiliki jam operasi yang nyaman. Dimensi ini merupakan gabungan dari dimensi-dimensi: a) access: menunjukkan kemudahan dari penyedia jasa untuk dihubungi, b) communication: menunjukkan penyedia jasa yang selalu mengkomunikasikan kepada pelanggan agar pelanggan memahami pelayanannya dengan baik, c) Understanding the Customer: menunjukan penyedia jasa berusaha untuk mengetahui pelanggan dan kebutuhannya.

\section{METODE PENELITIAN Ukuran Sampel}

Jumlah contoh yang diambil adalah sebesar 1529 sampel, dari jumlah populasi pelanggan PDAM sebesar 35.058 Sambungan Rumah (SR) dengan wilayah pelayanan PDAM di Bekasi Barat dan Bekasi Utara. Jumlah sampel tersebut diperoleh dengan menggunakan teknik pengambilan sampel oleh Taro Yamane (1960) dengan tingkat error sebesar 4,4 persen.

$$
n=\frac{N}{N d^{2}+1}
$$

di mana :

$n=$ jumlah sampel

$N=$ jumlah populasi

$d^{2}=$ Presisi yang ditetapkan $0,044(4,4 \%)$

Dari sampel yang diperoleh, kemudian dilakukan pendistribusian dengan menggunakan cluster sampling/ area sampling, Teknik ini digunakan secara proporsional dikarenakan objek sampel terdiri dari kelompok-kelompok individu atau cluster berdasarkan area dalam 71 wilayah perumahan yang dilayani PDAM. Teknik area sampling menurut Sugiyono (2011:83) dapat digunakan untuk menentukan sampel bila 
obyek yang akan diteliti atau sumber data sangat luas, misal penduduk dari suatu negara, provinsi, kota atau kabupaten. Dengan menggunakan teknik ini, peneliti lebih dapat menghemat biaya dan tenaga dalam menemui responden yang menjadi obyek penelitian.

\section{Kuesioner}

Kuesioner digunakan untuk membantu memudahkan pengumpulan data dan informasi dari pelanggan mengenai kinerja PDAM. Adapun skala yang digunakan untuk mengukur kinerja PDAM digunakan Semantic Differential (skala 1-4), dimana penggunaannya bertujuan: (1) untuk mengukur secara objektif sifat-sifat semantik dari kata atau konsep dalam ruang semantik tiga dimensional dan (2) sebagai skala sikap yang memusatkan perhatian pada aspek afektif atau dimensi evaluatif. Osgood dkk (Issac dan Michael, 1984: 145). Skala ini juga diukur untuk mengukur sikap. Data yang diperoleh adalah data interval, dan biasanya skala ini digunakan untuk mengukur sikap/karakteristik yang dimiliki oleh seseorang. Responden dapat memberi jawaban, pada rentang jawaban yang positif sampai dengan negatif (Sugiyono,2011:97)

\section{Metode Importance Performance Analysis (IPA)}

Teknik analisis Importance Performance Analysis (IPA) dikemukakan pertama kali oleh John. A. Martilla dan John C. James (1977). Metode ini mengidentifikasi dan memperbaiki kekurangan kualitas layanan dan meningkatkan persepsi penerima layanan menurut Izadi (2017). Dalam teknik ini responden diminta untuk membuat peringkat berbagai atribut atau elemen dari penawaran berdasarkan derajat pentingnya setiap atribut tersebut. Selain derajat kepentingan, responden juga diminta membuat peringkat seberapa baik kinerja perusahaan dalam masing-masing atribut yang diperingkatkan pada derajat kepentingan, sehingga hasilnya dapat dianalisis dengan menggunakan kuadran.

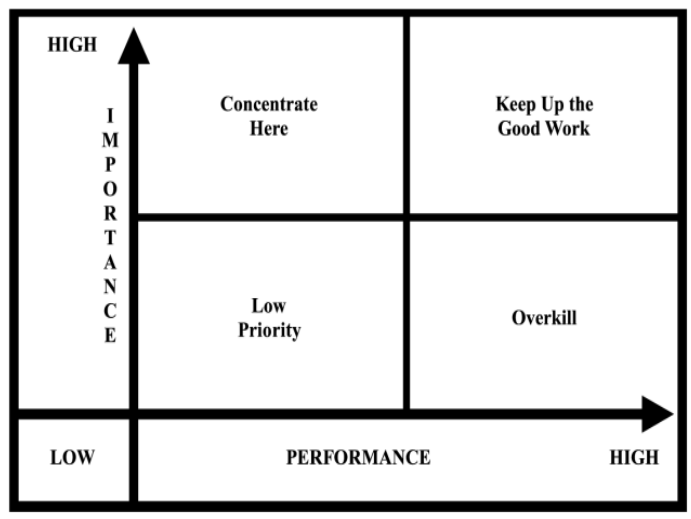

Sumber: Martilla \& James, 1977

Gambar 2. Kuadran Importance Performance Analysis

Interpretasi dari kuadran di atas adalah sebagai berikut: Pertama, pertahankan Prestasi (Keep Up The Good Work). Kuadran ini menunjukkan atribut-atribut yang dianggap penting dan juga pelaksanaan atribut ini memenuhi standar yang tinggi atau prima. Atribut yang masuk ke dalam kuadran ini harus dipertahankan agar tetap berada pada tingkat kinerja yang sama.

Kedua, berlebihan (possibly overkill). Kuadran ini menunjukkan adanya atributatribut yang yang memperoleh alokasi sumberdaya berlebihan, dan menampilkan kinerja yang prima, namun atribut-atribut ini dianggap tidak terlalu penting dan tidak terlalu diharapkan oleh pelanggan sehingga upaya yang digunakan untuk memperoleh kinerja prima yang telah ditunjukkan dapat dikatakan berlebihan. Perusahaan lebih baik mengalokasikan sumber daya yang terkait pada faktor tersebut kepada factor lain yang lebih memiliki tingkat prioritas lebih tinggi.

Ketiga, prioritas rendah (low priority). Kuadran ini menunjukkan atribut yang berada di dalamnya mempunyai tingkat persepsi atau kinerja aktual yang rendah dan tidak terlalu penting dan atau tidak terlalu diharapkan oleh konsumen sehingga tidak perlu diprioritaskan atau diberikan perhatian lebih. 
Keempat, prioritas utama (concentrate here). Kuadran ini menunjukkan atribut yang dianggap penting dan diharapkan, namun pelaksanaannya belum memenuhi standar kinerja atau tingkat harapan yang diinginkan konsumen. Apabila atribut masuk ke dalam kuadran ini, maka diperlukan upaya-upaya yang terkonsentrasi menggeser atribut tersebut ke kuadran satu (atas kanan). Perusahaan perlu berkonsentrasi untuk mengalokasikan sumber dayanya guna meningkatkan performa yang masuk pada kuadran ini.

Tabel 1. Skala Semantic

\begin{tabular}{ccc}
\hline Skor & Tingkat Kinerja & $\begin{array}{c}\text { Tingkat } \\
\text { Kepentingan }\end{array}$ \\
\hline 4 & Sangat Baik & Sangat Penting \\
\hline 3 & Baik & Penting \\
\hline 2 & Tidak Baik & Tidak Penting \\
\hline 1 & Sangat tidak Baik & $\begin{array}{c}\text { Sangat Tidak } \\
\text { Penting }\end{array}$ \\
\hline
\end{tabular}

Analisis diawal dengan menyebarkan kuesioner ke pelanggan satu per satu dari rumah ke rumah, setiap pertanyaan memiliki 1 pertanyaan dengan 2 jawaban untuk mengukur tingkat kepentingan dan kinerjanya, apakah menurut pelanggan hal tersebut penting dilakukan atau dilaksanakan dan bagaiman kinerjanya, baik atau tidak baik.

Metode IPA ini menggunakan bantuan diagram kartesius untuk menggambarkan kondisi kinerja dan kepentingan yang ditentukan oleh pelanggan. sehingga diperlukan koordinat yang diperoleh dari nilai rata-rata skor tingkat kepentingan dan tingkat harapan dari pelanggan. Adapun rumus yang digunakan adalah:

$$
\begin{gathered}
\bar{X}=\frac{\sum X i}{n} \\
\overline{(2)} \\
\bar{Y}=\frac{\sum X i}{n}
\end{gathered}
$$

di mana,

$\bar{X}=$ Skor rata-rata tingkat Kinerja

$\bar{Y}=$ Skor rata-rata tingkat kepentingan

$\mathrm{n}=$ Jumlah responden

Pada sumbu $(Y)$ vertikal merupakan skor tingkat kepentingan, dan pada sumbu mendatar (X) skor tingkat pelaksanaan/realita. Setelah rata-rata diperoleh kemudian dicari rata-rata dari selutuh sampel pada setiap atribut pertanyaan dengan menggunakan rumus sebagai berikut:

$$
\overline{\bar{X}}=\frac{\sum_{i=1}^{k} \overline{X l}}{n}
$$

$$
\overline{\bar{Y}}=\frac{\sum_{i=1}^{k} \bar{Y} \iota}{n}
$$

(5)

Keterangan:

$\mathrm{K}=$ Banyak faktor atau atribut yang mempengaruhi kepuasan konsumen.

\section{HASIL PENELITIAN DAN PEMBAHASAN}

Pada jasa layanan yang diberikan PDAM kepada Pelanggan, terdapat beberapa Atribut yang diukur, antara lain adalah Pelayanan Administrasi, Kecepatan Pelayanan, Keadilan Mendapatkan Pelayanan, Kemampuan Petugas Pelayanan, Kemampuan Petugas Pelayanan Pelanggan, Kemampuan Petugas Call Center, Kemampuan Petugas Admin Media Sosial dan Website, Jadwal Waktu Pelayanan, Kemudahan Pembayaran Tagihan, dan Kenyamanan Tempat Pembayaran.

Indikator dari Kinerja dan Kepentingan pada pengukuran Jasa Layanan PDAM setelah diurutkan didapat nilai rata-rata untuk kinerja didapat angka 2,93 dan kepentingan pada angka 3,08 , nilai rata-rata tersebut digunakan sebagai standar kinerja dan kepentingan sekaligus sebagai titik potong dari garis tengah pada Teknik analisis Importance Performance Analysis (IPA). Pemeringkatan hasil kali antara indikator kepentingan dan kinerja didapat nilai 
atribut pembayaran memiliki hasil terbesar dengan nilai sebesar 9,30 sementara hasil terkecil pada atribut Kenyamanan Tempat Pembayaran dengan nilai 8,62. Hal ini menunjukkan kepuasan terhadap atribut pembayaran tagihan PDAM yang dilakukan setiap bulannya, dengan atribut kenyamanan tempat pembayaran di posisi terendah dapat diduga pembayaran yang dilakukan pelanggan mayoritas dilakukan di luar loket pembayaran.

Tabel 2. Nilai Atribut dari Indikator Kinerja dan Kepentingan

\begin{tabular}{|c|c|c|c|c|}
\hline URAIAN & KINERJA & KEPENTINGAN & Skor & IKP \\
\hline $\begin{array}{l}\text { Pelayanan } \\
\text { Administrasi }\end{array}$ & 2,94 & 3,06 & 8,98 & $73,49 \%$ \\
\hline Kecepatan Pelayanan & 2,89 & 3,11 & 9,00 & \\
\hline $\begin{array}{l}\text { Keadilan } \\
\text { Mendapatkan } \\
\text { Pelayanan }\end{array}$ & 2,92 & 3,06 & 8,96 & \\
\hline $\begin{array}{l}\text { Kemampuan Petugas } \\
\text { Pelayanan Pelanggan }\end{array}$ & 3,00 & 3,09 & 9,25 & \\
\hline $\begin{array}{l}\text { Kemampuan Petugas } \\
\text { Call Center }\end{array}$ & 2,98 & 3,09 & 9,21 & \\
\hline $\begin{array}{l}\text { Kemampuan Petugas } \\
\text { Admin Media Sosial \& } \\
\text { Website }\end{array}$ & 2,93 & 3,10 & 9,06 & \\
\hline $\begin{array}{l}\text { Jadwal Waktu } \\
\text { Pelayanan }\end{array}$ & 2,99 & 3,10 & 9,29 & \\
\hline Pembayaran Tagihan & 2,99 & 3,11 & 9,30 & \\
\hline $\begin{array}{l}\text { Kenyamanan Tempat } \\
\text { Pembayaran }\end{array}$ & 2,82 & 3,06 & 8,62 & \\
\hline Jumlah & 26,45 & 27,78 & $\begin{array}{c}81,6 \\
7\end{array}$ & \\
\hline Rata-rata & 2,94 & 3,09 & 9,07 & \\
\hline
\end{tabular}

Nilai Indeks Kepuasan Pelanggan didapat angka $73,49 \%$, nilai ini berada di atas $50 \%$ sehinga dapat dikategorikan baik. Nilainilai atribut dari indikator Kinerja dan Kepentingan yang terdapat pada tabel kemudian dilakukan pemetaan pada kuadran Kinerja dan Kepentingan, berdasarkan nilai Kinerja dan Kepentingan seperti pada gambar berikut. 


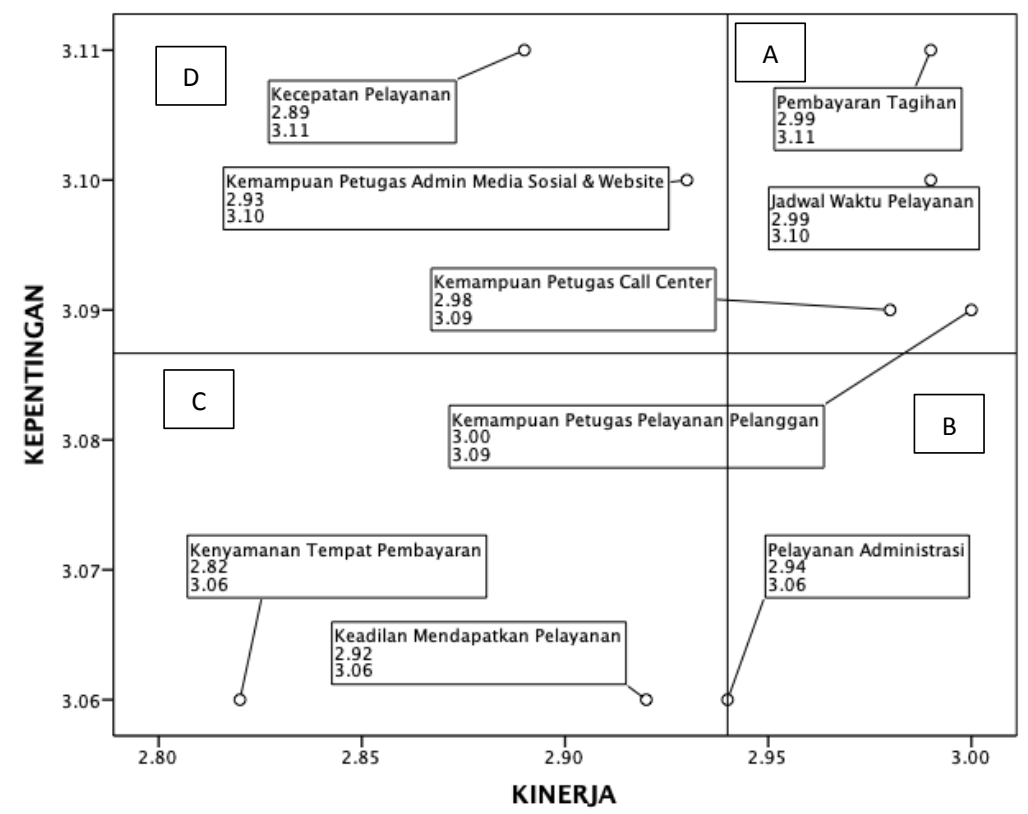

Gambar 3. Nilai Atribut dari Indikator Kinerja dan Kepentingan

Atribut yang tersebar dalam kuadran Kinerja dan kepentingan Kualitas Produk PDAM adalah sebagai berikut:

\section{Pertahankan Prestasi (Keep Up The Good Work)}

Atribut atribut pada Kuadran ini menunjukkan posisi atribut tersebut dianggap penting dan juga pelaksanaan atribut ini memenuhi standar yang tinggi atau prima. Dimana urutan dari atribut pada kuadaran ini meliputi Atribut Pembayaran Tagihan dengan nilai kinerja 2,99 dan nilai indikator Kepentingan sebesar 3,11. Atribut Jadwal Waktu Pelayanan dengan nilai kinerja 2,99 dan indikator kepentingan 3,10. Atribut Kemampuan Petugas Pelayanan Pelanggan dengan nilai indikator kinerja sebesar 3,00 dan nilai indikator kepentingan 3,09 serta Atribut Kemampuan Petugas Call Center dengan indikator kinerja sebesar 2,98 dan indikator kepentingan 3,09. Atribut-atribut pada kuadran ini harus dipertahankan agar tetap berada pada tingkat kinerja yang sama.

\section{Berlebihan (Possibly Overkill)}

Atribut Pelayanan Administrasi menjadi satu-satunya atribut di kuadran ini dengan nilai indikator Kinerja 2,94 dan nilai Indikator Kepentingan sebesar 3,06. Hal ini menunjukkan atribut ini dianggap tidak terlalu penting dan tidak terlalu diharapkan oleh pelanggan, dalam pakteknya bisa jadi perusahan telah mengalokasikan sumberdaya yang cukup dan telah melayani pelanggan dengan baik. Sosialisai ke pelanggan tentang kegiatan pelayanan yang dilakukan oleh PDAM dapat meningkatkan kesadaran pelanggan akan pentingnya kegiatan administrasi yang dilaksanakan perusahaan

\section{Prioritas Rendah (Low Priority)}

Kuadran ini berisikan atribut Keadilan Mendapatkan Pelayanan dengan nilai indikator kinerja 2,92 dan indikator kepentingan sebesar 3,06, serta atribut Kenyamanan Tempat Pembayaran dengan nilai Indikator kinerja sebesar 2,82 dan nilai indikator kepentingan sebesar 3,06.

atribut ini berada dalam kuadran Low Priority diduga sebagai dampak dari pergeseran pola pembayaran pelanggan yang bermigrasi dari loket di PDAM ke pembayaran Online di bank atau outlet lain. Intensitas interaksi antar pelanggan dan PDAM berkurang akibat 
perubahan pola pembayaran, hal ini yang menyebabkan kedua atribut ini menjadi tidak terlalu penting di mata pelanggan.

\section{Prioritas Utama (Concentrate Here)}

Kuadran ini menunjukkan atribut yang dianggap penting dan diharapkan, namun pelaksanaannya belum memenuhi standar kinerja atau tingkat harapan yang diinginkan konsumen. Adapun atribut yang ada pada kuadaran ini adalah atribut Kemampuan Petugas Admin Media Sosial \& Website dengan nilai indikator kinerja sebesar 2,93 dan nilai indikator kepentingan 3,10. Keadaan ini

\section{PENUTUP}

Indeks Kepuasan Pelanggan (IKP) untuk Jasa Pelayanan PDAM memiliki nilai sebesar $73,49 \%$ dan dapat dinyatakan memuaskan. Berdasarkan hasil survei yang telah dilakukan, maka penting bagi PDAM untuk memperbaiki kinerja, terutama dalam menangani masalah yang berkaitan erat dengan pelanggan. Perlunya dilakukan perbaikan terhadap variabel yang berkaitan dengan kinerja PDAM yang dinilai kurang oleh masyarakat. Dari semua atribut di Kategori Jasa terlihat secara mayoritas di semua zona kinerja PDAM masuk ke dalam kuadran (D) Concentrate Here, (C) Low Priority, dan (A) Keep Up The good Work, sementara untuk kuadran (B) Possibly Overkill hanya ditemukan satu yaitu Pelayanan Administrasi dengan kata lain pelayanan administrasi meskipun kinerjanya baik tidak dianggap penting oleh pelanggan.

Kuadran (D) Concentrate Here menunjukkan perlu ditingkatkan kecepatan pelayanan, dan kemampuan petugas media sosial. Kecepatan pelayanan memiliki nilai kepentingan yang paling tinggi di mata pelanggan namun kinerjanya berada pada posisi dua terendah, untuk itu peningkatan kecepatan pelayanan khususnya terkait dengan proses perbaikan dan pengangan keluhan perlu ditingkatkan. Kemampuan petugas media sosial muncul dikarenakan preferensi pelanggan dalam penggunaan dimungkinkan muncul akibat adanya ekspetasi dari pelanggan mengenai kemudahan penyampaian informasi dan pelayananan lainnya secara on line khususnya melalui Media Sosial, keberadaan Intipasi dirasa cukup membantu penyebaran informasi namun kinerjanya masih dianggap dibawah rata-rata.

Atribut lainya adalah atribut Kecepatan Pelayanan dengan nilai indikator kepentingan sebesar 2,89 dan indikator kepentingan sebesar 3,11. Nilai ini menunjukkan kinerja dari kecepatan pelayanan petugas PDAM yang masih dianggap dibawah rata-rata.

media sosial, namun belum dianggap penting dikarenakan pelanggan secara mayoritas masih mendapatkan informasi terbanyak melalui pesan singkat.

Dengan meningkatkan kinerja sesuai hasil temuan tersebut diharapkan nilai kepuasan pelanggan PDAM di masa yang akan datang akan mengalami peningkatan. Yang artinya masyarakat telah terlayani dengan baik.

\section{REFERENSI}

A. Zeithaml, et al. (1985). Problems and Strategies in Services Marketing. Jurnal of Marketing, Vol. 49. (Spring).

Esanawati, R. (2009) Analisis ekonomi fungsi produksi, penetapan tarif dan alokasi air minum yang efisien studi kasus: PDAM Kota Bekasi. Tersedia di http://repository.ipb.ac.id/handle/1234 56789/14166.

Greenberg, P. (2010). Customer Relationship Management as the Speed of Light. Fourth Edition. USA: McGraw-Hill

Issac, S. \& Michael, W.B. (1984). Handbook in research and evaluation. San Diego: Edits

Iswinarno, C. (2019). Sumber Air Baku Warga Bekasi Kembali Tercemar Limbah. Tersedia https://jabar.suara.com/read/2019/08/ 
20/180923/sumber-air-baku-warga-

bekasi-kembali-tercemar-limbah.

Izadi, A., et al. (2017). Evaluating health service quality: using importance performance analysis. International Journal of Health Care Quality Assurance, Vol. 30 No. 7, pp. 656-663.

Martilla, John A. and James, John C. (1977). Importance-Performance Analysis. The Journal of Marketing, Vol. 41, No. 1 (Jan, 1977), doi: https://doi.org/10.1177/002224297704 100112.

Sugiyono. (2011). Metode Penelitian Kuantitatif Kualitatif dan R\&D. Cetakan ke-14. Bandung: Penerbit Alfabeta

Supranto, J. (2011). Pengukuran Tingkat Kepuasan Pelanggan. Jakarta: Penerbit Rineka Cipta

Tjiptono, F. (2015). Strategi Pemasaran. Edisi 4. Yogyakarta: Penerbit Andi.

Tjiptono, F., dan Chandra, G. (2011). Service, Quality, \& Satisfaction. Edisi 3. Yogyakarta: Andi.

Yamane, T. (1967). Statistics, An Introductory Analysis. Second Edition. New York: Harper and Row.

Z. Yamit. (2005). Manajemen Kualitas Produk dan Jasa. Jakarta: Gramedia Pustaka Utama. 
